\title{
PROYEKSI PRODUKSI BERAS DAN STRATEGI MEWUJUDKAN SWASEMBADA BERAS DI KABUPATEN KETAPANG
}

\author{
Hendri Sibuea*, Erlinda Yurisinthae ${ }^{\star *}$, Novira Kusrini ${ }^{* *}$ \\ *Alumni Magister Manajemen Agribisnis Fakultas Pertanian \\ Universitas Tanjungpura Pontianak \\ ** Staf Pengajar Fakultas Pertanian Universitas Tanjungpura Pontianak
}

\begin{abstract}
Total rice production in Ketapang District compared with other districts in West Kalimantan is quite high, which is take the the fourth place in rice producing district in West Kalimantan Province. However, based on the development of rice production number is also known that rice production in Ketapang District experienced a significant decline, from a range of more than 100,000 tons per year down to less than 100,000 tons per year starting in 2008 (BPS Ketapang District, 2011). Based on its development, the rate of change in the availability of rice in Ketapang very volatile and tends to decrease, while the rate of population increase. This needs to be a concern because the population rate will always increase, so it must be balanced with stability increase of rice production, to fulfill the basic needs of the staple food of the community .
\end{abstract}

Based on the problem, this research aims to provide the projection of rice production and consumption in the next seven years and its implications for selfsufficiency in rice and to formulate appropriate strategies that should be implemented in order to achieve self-sufficiency in rice in Ketapang District. Analysis of projected production and consumption of rice in Ketapang calculated using Sofware Analysis of Food Consumption Patterns, with trend analysis approach, by considering the changes of the amount of food production and consumption within the last 5 years to predict the amount of rice production and consumption in the next 7 years. The data used are secondary data from annual data from BPS, namely Ketapang in Numbers 2007-2011. As for formulating strategies in order to achieve self-sufficiency in rice used SWOT analysis .

The analysis showed that the district can achieve rice surplus in 2016 if the rice harvested area and productivity can be increased respectively by $3 \%$ and $5 \%$, while still retaining the decline in rice consumption by $0.75 \%$ per year. Based on the results of the SWOT analysis appropriate strategy to be applied is progressive strategy, by focusing on the strength of Ketapang District. Thus, the formulation of a strategy that gained intensification and extension of land, diversification of food in community and institutional strengthening.

Key words : projections of production, self-sufficiency in rice

\section{PENDAHULUAN}

Beras merupakan komoditas yang penting karena merupakan kebutuhan pangan pokok yang setiap saat harus dipenuhi. Kebutuhan pangan pokok perlu diupayakan ketersediannya dalam jumlah yang cukup, mutu yang baik, aman dikonsumsi dan mudah diperoleh dengan harga yang terjangkau oleh seluruh lapisan masyarakat. Sesuai dengan arahan Presiden Republik Indonesia terkait program "Surplus Beras", dalam kurun waktu 5-10 tahun harus terjadi pergeseran dari kondisi swasembada beras menjadi surplus beras yang mencapai angka 10 juta ton per tahun. Dari jumlah tersebut, Provinsi Kalimantan Barat ditargetkan memiliki kontribusi surplus beras sebanyak 350.000 ton pada tahun 2014. Berdasarkan Prognosa tahun 2013 produksi padi di Provinsi Kalimantan Barat mencapai 1.457.535 Ton GKG, dengan luas luas panen $464.653 \mathrm{Ha}$, dan produktivitas sebesar $31,37 \mathrm{Kw} / \mathrm{Ha}$. Produksi beras bersih di Provinsi Kalimantan Barat berdasarkan produksi tersebut diperkirakan sebesar 804.843 Ton. Dengan proyeksi 
jumlah penduduk pertengahan tahun 2013 sebanyak 4.660 .750 jiwa dan konsumsi beras per kapita/tahun 139,15 Kg, maka kebutuhan beras penduduk pada tahun 2013 diperkirakan sebanyak 648.543 Ton (Dinas Pertanian Tanaman Pangan dan Hortikultura Kalbar, 2013).

Berdasarkan perhitungan tersebut maka pada tahun 2013 ini Provinsi Kalimantan Barat mengalami surplus beras sebanyak 156.300 Ton. Namun untuk mencapai surplus 350.000 Ton pada tahun 2014 masih diperlukan penambahan surplus sebanyak 193.700 Ton. (Dinas Pertanian Pangan dan Hortikultura, 2013).

Kabupaten Ketapang menempati urutan keenam sebagai kabupaten penghasil padi. Pada tahun 2006 dan 2007 produksi padi Kabupaten Ketapang berada kisaran di atas 100.000 ton, yaitu 143.582 ton pada tahun 2006 dan 153.116 ton pada tahun 2007. Namun sejak tahun 2008 produksi padi Kabupaten Ketapang mengalami penurunan hingga berada di bawah kisaran 100.000 ton per tahun (BPS Kabupaten Ketapang, 20082012). Namun dalam kurun waktu 2008-2012 terlihat perbedaan kecenderungan antara luas panen dan produktivitas padi di Kabupaten Ketapang. Luas panen padi secara total mengalami penurunan, sedangkan produktivitas padi cenderung mengalami peningkatan walaupun terjadi penurunan produktivitas.

Laju perubahan ketersediaan beras di Kabupaten Ketapang sangat fluktuatif dan cenderung menurun, sedangkan laju pertambahan penduduk semakin meningkat. Hal ini perlu menjadi perhatian karena laju pertambahan penduduk akan selalu bertambah, sehingga harus diimbangi dengan kestabilan pertambahan produksi beras untuk memenuhi kebutuhan pokok masyarakat.

Perumusan strategi yang tepat dapat menjadi jawaban terhadap permasalahan yang dihadapi tersebut. Namun perumusan strategi harus tepat guna dan tepat sasaran, demi tercapainya kondisi ideal bagi Kabupaten Ketapang sebagai daerah yang mampu memenuhi kebutuhan pangan masyarakatnya secara berkelanjutan. Oleh karena itu, untuk menunjang perumusan kebijakan tersebut perlu dilakukan pengumpulan informasi serta kajian terhadap kondisi produksi serta konsumsi beras di Kabupaten Ketapang. Berdasarkan uraian tersebut, maka penelitian ini bertujuan untuk memproyeksikan produksi dan konsumsi beras dalam tujuh tahun mendatang dan implikasinya terhadap swasembada beras, serta merumuskan strategi yang tepat yang harus dilaksanakan dalam rangka mencapai swasembada beras di Kabupaten Ketapang.

\section{METODOLOGI}

Penelitian dilakukan di Kabupaten Ketapang yang terdiri dari 20 Kecamatan. Jenis data dalam penelitian terdiri dari data sekunder dan data primer.

Data sekunder yang digunakan yaitu data yang terkait produksi dan konsumsi beras di Kabupaten Ketapang selama 5 tahun terakhir serta jumlah penduduk, yang diperoleh dari instansi terkait, terdiri dari :

1. Badan Pusat Statistik Kabupaten Ketapang; dan

2. Dinas Pertanian Kabupaten Ketapang.

Data primer dalam penelitian ini digunakan dalam pembahasan strategi mewujudkan swasembada beras di Kabupaten Ketapang, yang diperoleh dari para pihak yang berkompeten dalam menentukan strategi terkait swasembada beras, yang terdiri dari faktor-faktor yang tergolong dalam kekuatan dan kelemahan serta peluang dan ancaman yang dihadapi, dengan menggunakan instrumen penelitian berupa kuisioner di setiap bagian kerja yang ada di Dinas Pertanian Kabupaten Ketapang.

Proyeksi produksi dan konsumsi beras akan dihitung dengan menggunakan Sofware Analisis Pola Konsumsi Pangan. Perhitungan proyeksi produksi dan konsumsi 
tersebut dihitung dengan pendekatan analisis trend, yaitu analisis time series dengan melihat perubahan jumlah produksi dan konsumsi pangan dalam kurun waktu 5 tahun terakhir, untuk memprediksikan jumlah produksi dan konsumsi dalam kurun waktu 5 tahun ke depan. Langkah-langkah yang dilakukan dalam menganalisis proyeksi produksi dan konsumsi beras dengan menggunakan Sofware Analisis Pola Konsumsi Pangan tersebut adalah sebagai berikut:

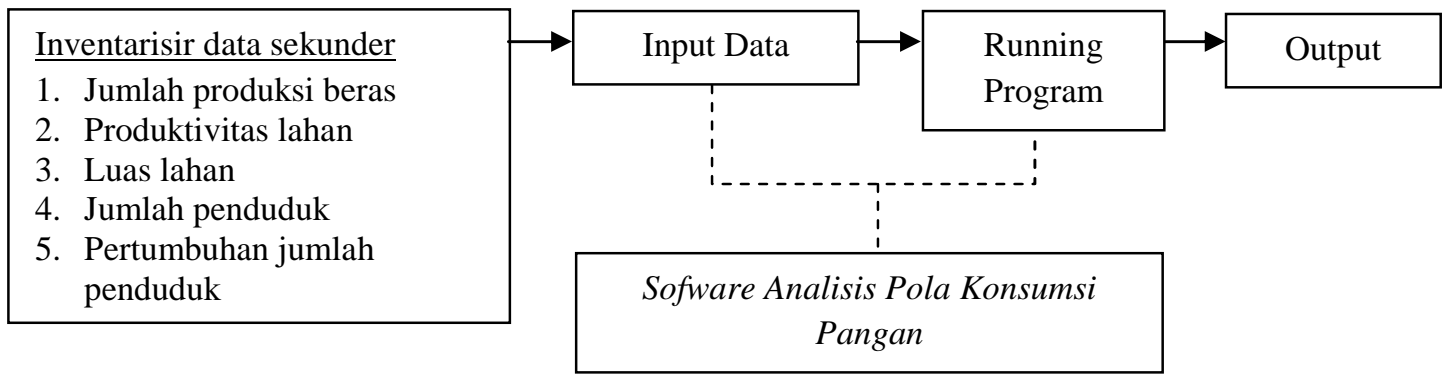

\section{Skema Langkah Analisis Proyeksi Produksi dan Konsumsi Beras dengan Software Analisis Pola Konsumsi Pangan}

Untuk merumuskan strategi dalam mewujudkan swasembada beras dalam penelitian ini digunakan Analisis SWOT dengan langkah sebagai berikut:

1. Menentukan pihak-pihak yang kompeten dalam merumuskan keempat unsur dalam analisis SWOT dan berkaitan langsung dengan permasalahan yang diangkat dalam penelitian ini.

2. Mengelompokkan pernyataan dari masing-masing narasumber ke dalam keempat unsur analisis, yaitu kekuatan dan kelemahan serta peluang dan ancaman;

3. Menentukan unsur utama yang dapat dijadikan sebagai faktor penentu dalam merumuskan strategi;

4. Merumuskan stretegi yang paling tepat untuk mencapai swasembada beras dengan berdasarkan pada faktor penentu utama.

\section{HASIL DAN PEMBAHASAN}

\section{A. Proyeksi Pada Tingkat Konsumsi Pangan dan Penyediaannya}

Perhitungan untuk menentukan proyeksi konsumsi jumlah pangan penduduk Kabupaten Ketapang digunakan asumsi pertumbuhan penduduk tiap tahunnya meningkat 2,58\%, berdasarkan proyeksi pertumbuhan penduduk dari BPS, dimana jumlah penduduk Tahun 2013 sebanyak 437.613 jiwa (Ketapang Dalam Angka, 2012).

Untuk mendapatkan hasil analisis yang lebih mendalam, maka dalam perhitungan proyeksi konsumsi dipergunakan 3 skenario yaitu :

1. Skenario I : Proyeksi konsumsi mempertimbangkan Angka Kecukupan Energi (AKG) yang seharusnya dipenuhi oleh setiap jiwa. Adapun Standar AKG untuk konsumsi pangan adalah $2.000 \mathrm{kkal} / \mathrm{kap} / \mathrm{hari}$ sedangkan ketersediaan pangan adalah $2.200 \mathrm{kkal} / \mathrm{kap} / \mathrm{hari}$ yang akan digunakan untuk penentuan penyediaan pangan aktual dan proyeksi (Widyakarya Nasional Pangan dan Gizi, 2004).

2. Skenario II: Pada kondisi ini, proyeksi konsumsi ke depan (2014-2020) jauh lebih besar dibandingkan Skenario I dikarenakan diasumsikan tiap tahun konsumsi beras tetap $125,1 \mathrm{~kg} / \mathrm{kapita}$ sedangkan jumlah penduduk Ketapang yang juga semakin meningkat sebesar $2,58 \%$ per tahun. 
3. Skenario III : Pada kondisi ini, proyeksi konsumsi ke depan (2014-2020) jauh lebih besar dibandingkan Skenario I dan II, karena diasumsikan tiap tahun penduduk Ketapang konsumsi berasnya meningkat menjadi 134,37 kg/kapita sedangkan jumlah penduduk Ketapang yang juga semakin meningkat sebesar 2,58\% per tahun.

\section{Proyeksi Peningkatan Produksi}

Berdasarkan hasil permodelan yang dilakukan oleh Syafaat, et all (2005) dalam melakukan perencanaan produksi, seorang produsen dapat menempuh 2 (dua) tahapan pengambilan keputusan, yaitu : (1) luas areal yang akan ditanami dan (2) perolehan hasil (produktivitas) per satuan luas tanaman yang diusahakan. Dengan demikian, ada dua faktor yang dipertimbangkan dalam memproyeksikan produksi padi, yaitu luas panen dan produktivitas. Sama halnya dengan proyeksi konsumsi, proyeksi produksi ini dilakukan dengan 3 skenario sebagai berikut :

Tabel 1. Skenario Proyeksi Produksi Padi

\begin{tabular}{lll}
\hline Skenario & Luas Panen & Produktivitas \\
\hline \hline Skenario 1 (pesimis) & Naik 5\% per tahun & Tetap pada 2,9 ton/ha/thn ${ }^{1)}$ \\
Skenario 2 & Naik 5\% per tahun & Naik 3\% per tahun \\
Skenario 3 & Turun 1\% per tahun & Naik 8\% per tahun \\
\hline
\end{tabular}

Keterangan :

1) Produktivitas mengacu pada kondisi aktual (Tahun 2103)

\section{Proyeksi Surplus/Defisit}

Surplus/defisit beras hanya dihitung untuk konsumsi langsung saja karena konsumsi untuk non pangan sudah dikurangkan pada proyeksi produksi. Proyeksi surplus/defisit akan dijelaskan sesuai dengan masing-masing skenario proyeksi produksi dengan skenario proyeksi konsumsi pada tingkat penyediaan.

\section{1) Proyeksi Peningkatan Produksi (SKENARIO I)}

Skenario ini mengasumsikan terjadinya kenaikan luas panen $5 \%$ per tahun sedangkan produktivitas tetap mengacu ada tahun 2013 yaitu 2,9 ton/ha. Pada kondisi ini akan dibandingkan dengan masing-masing skenario proyeksi konsumsi untuk mengetahui apakah terjadi gap/kesenjangan sehingga dapat dilihat apakah terjadi surplus/defisit beras.

a. Pada skenario I (proyeksi konsumsi) : pada kondisi ini, rata-rata konsumsi beras mengalami penurunan sebesar $-0.72 \%$ per tahun. Status Kabupaten Ketapang sebagai daerah yang berswasembada beras dicapai mulai tahun 2017 sampai tahun akhir proyeksi.

b. Pada skenario II (proyeksi konsumsi) : pada kondisi ini, tingkat konsumsi tetap $125,1 \mathrm{~kg} / \mathrm{kap} / \mathrm{thn}$ seperti tahun 2013. Status Kabupaten Ketapang akan tetap sebagai daerah yang defisit beras sampai akhir tahun proyeksi walaupun sudah dilakukan penambahan luas panen.

c. Pada skenario III (proyeksi konsumsi) : pada kondisi ini, tingkat konsumsi sebesar $134,37 \mathrm{~kg} / \mathrm{kap} / \mathrm{thn}$ sesuai dengan tingkat konsumsi pangan nasional. Status Kabupaten Ketapang akan menjadi lebih buruk sebagai daerah yang defisit beras sampai akhir tahun proyeksi walaupun sudah dilakukan penambahan luas panen. 


\section{2) Proyeksi Peningkatan Produksi (SKENARIO II)}

Skenario ini mengasumsikan terjadi kenaikan luas panen $5 \%$ per tahun dan produktivitas naik $3 \%$ per tahun. Pada kondisi ini akan dibandingkan dengan masingmasing skenario proyeksi konsumsi untuk mengetahui apakah terjadi gap/kesenjangan sehingga dapat dilihat apakah terjadi surplus/defisit beras.

a. Pada skenario I (proyeksi konsumsi) : pada kondisi ini, rata-rata konsumsi beras mengalami penurunan sebesar $0.72 \%$ per tahun. Status Kabupaten Ketapang sebagai daerah yang berswasembada beras bisa dicapai lebih awal yaitu tahun 2016 sampai tahun akhir proyeksi dibandingkan dengan skenario produksi I.

b. Pada skenario II (proyeksi konsumsi) : pada kondisi ini, tingkat konsumsi tetap $125,1 \mathrm{~kg} / \mathrm{kap} / \mathrm{thn}$ seperti tahun 2013. Status Kabupaten Ketapang akan tetap sebagai daerah yang defisit beras hanya sampai tahun 2018 karena tahun 2019 sudah tercapai surplus.

c. Pada skenario III (proyeksi konsumsi) : pada kondisi ini, tingkat konsumsi sebesar $134,37 \mathrm{~kg} / \mathrm{kap} / \mathrm{thn}$ sesuai dengan tingkat konsumsi pangan nasional. Status Kabupaten Ketapang juga akan tetap sebagai daerah yang defisit beras sampai tahun 2019 dan pada akhir tahun proyeksi 2020 dapat dicapai surplus beras.

\section{3) Proyeksi Peningkatan Produksi (SKENARIO III)}

Skenario ini mengasumsikan terjadi penurunan luas panen $1 \%$ per tahun dan produktivitas naik $8 \%$ per tahun. Pada kondisi ini akan dibandingkan dengan masingmasing skenario proyeksi konsumsi untuk mengetahui apakah terjadi gap/kesenjangan sehingga dapat dilihat apakah terjadi surplus/defisit beras.

a. Pada skenario I (proyeksi konsumsi) : pada kondisi ini, rata-rata konsumsi beras mengalami penurunan sebesar $0.72 \%$ per tahun. Status Kabupaten Ketapang sebagai daerah yang berswasembada beras bisa dicapai tahun 2017.

b. skenario II (proyeksi konsumsi) : pada kondisi ini, tingkat konsumsi tetap 125,1 $\mathrm{kg} / \mathrm{kap} / \mathrm{thn}$ seperti tahun 2013. Status Kabupaten Ketapang akan tetap sebagai daerah yang defisit beras sampai akhir tahun proyeksi.

c. Pada skenario III (proyeksi konsumsi) : pada kondisi ini, tingkat konsumsi sebesar $134,37 \mathrm{~kg} / \mathrm{kap} / \mathrm{thn}$ sesuai dengan tingkat konsumsi pangan nasional. Status Kabupaten Ketapang akan menjadi lebih buruk dibandingkan skenario II (proyeksi konsumsi) sebagai daerah yang defisit beras sampai akhir tahun proyeksi.

Berdasarkan uraian di atas maka dapat diambill beberapa temuan penting sehubungan dengan proyeksi peningkatan produksi :

1. Skenario peningkatan produksi (Skenario II) jelas lebih baik dibandingkan dengan skenario lainnya dikarenakan terjadi peningkatan baik luas panen dan produktivitas masing-masing 5\% per tahun dan 3\% per tahun.

2. Bila dibandingkan antara skenario peningkatan produksi skenario I dan skenario peningkatan produksi skenario II. Skenario I adalah skenario yang paling buruk walaupun terjadi peningkatan luas panen per tahun sebesar $1 \%$. Hal ini dibuktikan dari 2 (dua) hal yaitu :

(a) Bila dilihat dari hasil proyeksi surplus/defisit, pada skenario peningkatan produksi skenario I dimana keadaan surplus pada skenario I proyeksi konsumsi, yang tercapai pada tahun 2017-2020 nilainya lebih kecil dibandingkan skenario peningkatan produksi skenario III. 
(b) Begitu halnya dengan jumlah defisit tahun 2014-2020, pada skenario peningkatan produksi skenario I, khususnya skenario II dan III proyeksi konsumsi lebih besar dibandingkan skenario peningkatan produksi skenario III.

3. Bila dilihat dari kolaborasi antara skenario peningkatan produksi dan konsumsi, skenario yang ideal adalah penggabungan antara skenario II peningkatan produksi dengan skenario I proyeksi konsumsi. Hal ini dibuktikan dari hasil proyeksi tersebut swasembada beras dicapai lebh awal yaitu pada tahun 2016 dibandingkan skenario lainnya sehingga diharapkan ketersediaan beras untuk konsumsi pangan juga untuk non pangan bisa dicukupi dari daerah sendiri. Hal ini dapat dicapai bila ada perbaikan tidak hanya dari sisi produksi tetapi juga dibarengi dengan perbaikan konsumsi penduduk Ketapang.

\section{B. Analisis Strategi Mencapai Swasembada Beras}

Perumusan strategi mencapai swasembada beras dimulai dari identifikasi isu-isu yang terkait yang memiliki pengaruh terhadap terhadap ketersediaan beras di Kabupaten Ketapang, yaitu dari aspek sektor pertanian maupun kondisi usahatani di Kabupaten Ketapang, aspek kelembagaan dan sspek demografis.

Hasil analisis menunjukkan bahwa seluruh faktor dalam aspek kelembagaan tergolong sebagai kekuatan dalam mendukung terwujudnya swasembada beras di Kabupaten Ketapang. Faktor-faktor kondisi demografi ternyata cenderung tergolong dalam kelemahan dalam mendukung terwujudnya swasembada beras di Kabupaten Ketapang. Hal tersebut terlihat dari hampir semua faktor tergolong sebagai kelemahan, hanya satu yang tergolong sebagai kekuatan, yaitu faktor penduduk.

Hasil analisis SWOT menunjukkan bahwa untuk mencapai kondisi swasembada beras diperlukan strategi progresif artinya organisasi berada dalam kondisi prima dan mantap sehingga sangat dimungkinkan untuk terus melakukan ekspansi, memperbesar pertumbuhan dan meraih kemajuan secara maksimal, dengan memanfaatkan kekuatan yang dimiliki dan peluang yang dihadapinya.

Berdasarkan hasil analisis maka upaya untuk mencapai swasembada beras di Kabupaten Ketapang dapat dilakukan melalui beberapa langkah strategis yaitu dengan cara intensifikasi dan ekstensifikasi lahan, diversifikasi pangan di masyarakat dan penguatan kelembagaan.

\section{KESIMPULAN}

Hasil analisis proyeksi menunjukkan bahwa skenario yang ideal untuk mencapai kondisi swasembada beras di Kabupaten Ketapang adalah penggabungan antara skenario II peningkatan produksi dengan skenario I proyeksi konsumsi. Hal ini dibuktikan dari hasil proyeksi tersebut swasembada beras dicapai lebh awal yaitu pada tahun 2016 dibandingkan skenario lainnya sehingga diharapkan ketersediaan beras untuk konsumsi pangan juga untuk non pangan bisa dicukupi dari daerah sendiri. Hal ini dapat dicapai bila ada perbaikan tidak hanya dari sisi produksi tetapi juga dibarengi dengan perbaikan konsumsi penduduk Ketapang

Berdasarkan analisis perumusan strategi yang dilakukan, dengan metode SWOT, maka diketahui bahwa strategi yang digunakan yaitu strategi progresif, yaitu dengan memfokuskan pada kekuatan yang dimiliki oleh Kabupaten Ketapang. Dengan demikian maka diperoleh beberapa rumusan strategi yaitu intensifikasi dan ekstensifikasi lahan, diversifikasi pangan di masyarakat dan penguatan kelembagaan 


\section{DAFTAR PUSTAKA}

Adriana, R. 2007. Penawaran Beras Dunia dan Permintaan Impor Beras Indonesia serta Kebijakan Perberasan di Indonesia. Skripsi. Fakultas Pertanian Institut Pertanian Bogor.

Adyana, M.O. 1999, Penerapan Model Penyesuaian Nerlove dalam Proyeksi Produksi dan Konsumsi Beras.

BPK. 2013. Kebijakan Pemerintah Dalam Pencapaian Swasembada Beras Pada Program Peningkatan Ketahanan Pangan. Diakses pada : http://jdih.bpk.go.id/wpcontent/uploads/2012/03/tulisan-hukum-ketahanan-pangan.pdf

BPS. 2007-2012. Kalimantan Barat Dalam Angka. Badan Pusat Statistik Kalimantan Barat : Pontianak.

. 2011. Berita Terkini : Jika Dihitung Indonesia Surplus Beras 4 Juta Ton. Diakses pada : http://www.berita-terbaru.com/berita-nasional/bps-thn-2011seharusnya-beras-surplus-4jt-ton-tapi-kemana-yah-larinya-ayo-tebak.html.

Dan Schendel dan Charles Higgins. 1985. Pengambilan Keputusan Stratejik. Untuk organisasi public dan Organisasi Non Profit. Grasindo. Jakarta.

Departemen Pertanian. 1969-2006. Data Based Komoditas Padi. Departemen Pertanian Republik Indonesia : Jakarta.

Dinas Pertanian Pangan dan Hortikultura Provinsi Kalimantan Barat. 2013. Sosialisasi Program Kerjasama TNI AD dengan Kementerian Pertanian. Dinasi Pertanian dan Hortikultura Provinsi Kalimantan Barat : Pontianak.

FAO (Food and Agriculture Organization). 2001. ROA Project Publication No. 2 : Expert Meeting Proceeding : Rome, Italy.

Glueck, W.F. dan Jauch, L.R. 1989. Strategy Analysis : Concept, Technique and Application. The Blackwell Publishers inc. Oxford.

Hanani, Nuhfil. 2009. Ketersediaan dan Kemandirian Pangan. Universitas Brawijaya. Diakses pada : http://lecture.brawijaya.ac.id.

Hariadi, Bambang. 2005. Strategi Manajemen. Bayumedia Publishing. Jakarta.

Husein, Umar. 1997. Metodologi Penelitian Aplikasi Dalam Pemasaran. Gramedia. Jakarta.

Nazir, M. 1988. Metode Penelitian. Penerbit Ghalia Indonesia. Jakarta.

Nurmalina, R. 2007. Model Ketersediaan Beras Yang Berkelanjutan untuk mendukung ketahanan pangan nasional. Program studi pengelolaan sumberdaya alam dan lingkungan (PSL). Sekolah Pascasarjana. Institut Pertanian Bogor : Bogor.

Pearce, John A. II And Richard B. Robinson Jr. 1998. Strategic Management, 3rd Edition. Richard D. Irwin, Illions : USA.

Pemerintah Provinsi Kalimantan Timur. 2013. Empat Langkah Strategis Capai Swasembada Beras. Diakses pada : http://www.kaltimprov.go.id/berita-1128empat-langkah-strategis-capai-swasembada-beras.html

Soetrisna, N. 2005. Strategi Pengembangan Ketahanan Pangan. Artike - Tahun XIV No. 44, Januari. Majalah Pangan. Puslitbang Bulog : Jakarta.

Suryana, Ahmad. 2003. Ketahanan Pangan dan Pembangunan Pertanian Kota. Diakses pada : http://www.suarapembaruan.com.html 